\title{
Pelatihan Karya Tulis Ilmiah bagi Mahasiswa
}

\author{
*Deddy Yusuf Yudhyarta ${ }^{1)}$, Erma Susanti' ${ }^{2)}$, M. Ilyas ${ }^{3)}$ \\ ${ }^{1,3)}$ Program Studi PAI STAI Auliaurrasyidin Tembilahan, Indragiri Hilir, Riau, Indonesia \\ ${ }^{2}$ Program Studi PGMI STAI Auliaurrasyidin Tembilahan, Indragiri Hilir, Riau, Indonesia \\ 4)Program Studi ESy STAI Auliaurrasyidin Tembilahan, Indragiri Hilir, Riau, Indonesia \\ Email: deddy.yusuf@stai-tbh.ac.id ${ }^{1}$; erma.susanti@ stai-tbh.ac.id $^{2}$; muhammad.ilyas@ stai-tbh.ac.id $^{3}$
}

\author{
Cara Mensitasi Artikel ini: \\ Yudhyarta, D. Y., Susanti, E., \& Ilyas, M. (2021). Pelatihan karya tulis ilmiah bagi mahasiswa. ABDIMASY: Jurnal \\ Pengabdian dan Pemberdayaan Masyarakat, 2(1), 1-10. https://doi.org/10.46963/ams.v2i1.338
}

\section{Sejarah Artikel \\ Diterima :09/06/2021 \\ Direvisi : 14/06/2021 \\ Diterbitkan : 29/06/2021 \\ *) Corresponding Author deddy.yusuf@stai-tbh.ac.id}

\section{$\underline{\text { DOI }}$}

https://doi.org/10.46963/ams.v2i1.338

\section{Kata Kunci: \\ Menulis; Karya tulis ilmiah; \\ Pelatihan penulisan}

Keywords:

Writing; Scientific papers; training

\section{Editorial Address}

Kampus Panam (Parit Enam) STAI Auliaurrasyidin, Jl. Gerilya No. 12 Tembilahan Barat, Riau, Indonesia, 29213 abdimasy@stai-tbh.ac.id

\begin{abstract}
The purpose of this training was the preparation of scientific writing and assistance in the practice of writing a research paper. The output will be in the form of a proposal and a draft report. This training activity was carried out for a month, In the first session, trainees were given different materials and assignments for writing scientific papers. In the second stage, participants were required to write scientific papers using mentoring, participatory, and guided methods. In the third stage, participants collected their assignments followed by discussions involving all personnel and training participants. This community service was carried out for sixth-semester students who were also studying their research papers at STAI Auliaurrasyidin Tembilahan.
\end{abstract}

Abstrak: Tujuan pelatihan ini adalah penyusunan materi tentang karya ilmiah dan pendampingan praktik penyusunan skripsi, diharapkan output berupa proposal dan rancangan laporan kemajuan skripsi. Kegiatan pelatihan ini dilaksanakan selama sebulan, mahasiswa diberikan materi yang berbeda-beda. Setelah diberikan materi, mahasiswa kemudian diberikan tugas untuk membuat karya tulis ilmiah. Selanjutnya, pada tahap kedua, peserta diwajibkan membuat karya ilmiah dengan menggunakan metode pendampingan, partisipasi, serta terbimbing. Tahap ketiga peserta mengumpulkan tugas karya ilmiah dilanjutkan dengan diskusi yang melibatkan semua personalia pengabdian dan peserta pelatihan. Pengabdian masyarakat ini dilakukan oleh mahasiswa semester enam dan mahasiswa yang sedang menyusun skripsi di STAI Auliaurrasyidin Tembilahan.

\section{PENDAHULUAN}

Ada berbagai cara yang dapat dilakukan seseorang untuk mengeluarkan ide, gagasan, dan pendapat kepada khalayak, yaitu dengan cara berbicara di depan umum atau dengan menulis artikel dan mempublikasikannya. Namun, untuk dapat berbicara di depan umum, tidak semua orang memiliki kesempatan dan kecakapan untuk menyampaikan pendapatnya. Oleh karena itu, sarana lain yang dapat digunakan adalah dengan media tulisan. 
Menulis merupakan kegiatan kreatif yang sangat penting karena seseorang dapat dengan mudah menyampaikan ide atau pendapatnya secara verbal ke khalayak. Pada zaman globalisasi saat ini, adanya internet sangat membantu untuk menyebarluaskan tulisan hingga ke seluruh dunia secara gratis. Hal ini bertolak belakang dengan zaman sebelum ada internet, di mana saat itu untuk membagikan suatu tulisan sangat sulit karena harus dicetak dalam surat kabar.

Pengertian menulis menurut Kamus Besar Bahasa Indonesia (KBBI) adalah kegiatan yang melahirkan pikiran atau perasaan dengan tulisan. Menurut pendapat para ahli, menulis adalah proses berpikir yang dilakukan secara berkesinambungan, mulai dari mencoba menulis, hingga mengulas hasil tulisan kembali (Abas, 2006).

Dari pengertian KBBI dapat kami simpulkan bahwa karya tulis merupakan hasil karangan dalam bentuk tulisan atau karangan yang mengetengahkan hasil pikiran, hasil pengamatan, tinjauan dalam bidang tertentu yang disusun secara sistematis. Karya tulis juga dapat dikatakan tulisan yang membahas masalah tertentu berdasarkan pengamatan secara sistematis dan terarah. Ada yang mengatakan karya tulis itu sebagai gagasan seseorang yang dituangkan dalam bentuk tulisan (Suherli, 2010). Dari berbagai pengertian yang ada pada dasarnya mempunyai arti yang sama namun dapat disimpulkan bahwa karya tulis merupakan hasil karya seseorang yang dituangkan dalam bentuk tulisan. Pendapat lainnya, menulis juga diartikan sebagai suatu tempat untuk menuangkan ide atau gagasan yang menggunakan bahasa tulis sebagai media penyampai (Tarigan, 1986). Pengertian menulis juga dideskripsikan oleh ahli lainnya yaitu sebagai kemampuan seseorang dalam mengeluarkan gagasan, perasaan, dan juga pemikiran-pemikirannya kepada orang atau pihak lain melalui media tulisan (Nurjamal, 2011).

Tujuan menulis adalah untuk merubah keyakinan pembaca, menanamkan pemahaman kepada pembaca, merangsang proses berpikir penulis, menghibur pembaca, dan memberikan informasi kepada pembaca (Syafie'ie, 1988).

Menulis juga memiliki manfaat yang sangat banyak sekali, yaitu untuk: 1 . Sarana untuk mengeluarkan ide atau pendapat yang ada pada alam bawah sadar manusia, 2. Sarana untuk memunculkan ide-ide baru, 3. Untuk melatih sifat objektif yang ada pada seseorang, 4. Menulis dapat membantu untuk memecahkan berbagai masalah, 5 . Menulis akan membantu seseorang agar menjadi aktif untuk mencari ilmu-ilmu yang baru (Widiastuti, 2013).

Suatu bentuk tulisan dapat dikategorikan menjadi dua yaitu tulisan ilmiah dan tulisan non ilmiah. Tulisan ilmiah adalah tulisan yang biasanya berkaitan dengan hasil dari suatu penelitian yang bersifat faktual dan akurat. Sementara, tulisan non ilmiah adalah tulisan yang berkaitan dengan opini atau gagasan seseorang yang bersifat subjektif yang bergantung pada sudut pandang penulis. Tulisan ilmiah biasanya banyak ditulis oleh para peneliti atau ahli dalam bidangnya masing-masing 
dan diterbitkan dalam suatu jurnal penelitian atau buku ajar. Sementara untuk tulisan non ilmiah biasanya dapat ditulis oleh siapa saja dan dapat diterbitkan di koran, majalah, dan lainnya.

Suatu tulisan yang baik biasanya dapat dengan mudah dimengerti dan dipahami oleh pembacanya. Untuk membuat tulisan yang baik bukanlah suatu pekerjaan yang mudah dan bahkan sering dikata kan menjadi pekerjaan yang sangat sulit bagi kebanyakan orang. Hal ini dapat terlihat dari fakta yang ada bahwa Indonesia sangat jauh tertinggal dari negara-negara lain dalam hal publikasi jurnal-jurnal penelitian internasional. Ketertinggalan ini sangat mungkin terjadi karena keterbatasan para peneliti dalam membahasakan hasil penelitian mereka dalam bentuk verbal. Fakta lainnya adalah banyaknya kasus plagiarisme yang terjadi di Indonesia dan bahkan kasus ini banyak menimpa para akademisi. (Khadarsiah, 2012).

Dengan adanya fakta-fakta tersebut memperlihatkan bahwa kemampuan menulis siswa-siswa di Indonesia masih sangat kurang ditambah lagi dengan minimnya pengetahuan para guru untuk mengajarkan metode pembuatan tulisan yang baik kepada remajanya. Remaja biasanya ada kegiatan yang bertujuan untuk mengasah kemampuan menulis yaitu KIR (Karya Ilmiah Remaja). KIR ini banyak melakukan kegiatan-kegiatan penelitian. Setelah dilakukan kegiatan penelitian biasanya para remaja akan ditugaskan untuk mengikuti lomba- loba penulisan karya ilmiah yang diadakan oleh institusi lainnya atau Perguruan Tinggi. Tujuan dari pelaksanaan lomba- lomba tersebut adalah untuk meningkatkan minat para siswa dalam meneliti dan untuk melaporkan hasil penelitian mereka dalam suatu karya tulis ilmiah remaja. Masalah kemudian yang muncul adalah para siswa ini tidak mampu untuk menuliskan hasil penelitian mereka dalam suatu tulisan yang baik. Para siswa biasanya hanya menuliskan hasilhasil penelitian tanpa didukung dengan teori yang jelas. Selain itu, tulisan mereka bersifat repetitif, kurang logis, dan tidak sistematis.

Hal-hal tersebut membuat mereka jarang memenangkan perlombaan karya tulis ilmiah yang ada, sehingga memberikan dampak yaitu mereka menjadi malas untuk melakukan penelitian.

Oleh karena itu, diperlukan pelatihan penulisan karya tulis ilmiah dengan metode yang tepat kepada para mahasiswa, sehingga mereka memiliki semangat kembali untuk melakukan penelitian dan menuliskan hasil-hasil penelitian mereka dalam suatu karya ilmiah. Setelah itu, diharapkan mereka mampu mengikuti lomba- lomba karya tulis ilmiah dan mampu memenangkan salah satu lomba tersebut.

\section{METODE}

Dengan adanya permasalahan tersebut, maka dilakukan kegiatan pengabdian masyarakat dengan cara memberikan pelatihan penulisan karya tulis ilmiah kepada 20 mahasiswa di STAI Auliaurrasyidin Tembilahan. Kegiatan pelatihan ini dilakukan selama sebulan, yaitu setiap hari minggu jam 08.00 hingga 09.30 WIB. Kegiatan pelatihan penulisan ini dilakukan di Ruangan STAI 
Auliaurrasyidin Tembilahan, di ruang kelas dengan menggunakan Laptop dan LCD proyektor.

Metode pembelajaran yang digunakan untuk mendukung keberhasilan program antara lain sebagai berikut:

1. Ceramah dan Tanya Jawab

Metode ini dipilih untuk membangkitkan motivasi guru dalam menulis karya ilmiah dan menjelaskan materi yang bersifat teoritis terkait dengan peraturan perundangan yang menyangkut kenaikan pangkat dan angka kredit. Selain itu juga membahas bermacam-macam karya tulis ilmiah termasuk laporan penelitian tindakan kelas.

2. Demonstrasi

Metode ini dipilih untuk menjelaskan sesuatu proses kerja secara bertahap sehingga dapat memberi kemudahan bagi peserta dapat mengamati secara cermat proses pembuatan karya tulis ilmiah dari persiapan sampai penyuntingan naskah.

3. Latihan/Praktik atau tutorial

Pada metode ini peserta mempraktikkan pembuatan karya tulis ilmiah dengan bimbingan pelatihan sehingga peserta dapat membuat karya tulis ilmiah dengan baik. Untuk mengetahui keberhasilan kegiatan ini, dilakukan dengan melihat keterlibatan dan antusias peserta. Keterlibatan peserta dapat dilihat dari absen peserta kegiatan dan antusiasme peserta dilihat dari motivasi peserta selama kegiatan berlangsung
Kegiatan pengabdian ini dilakukan dengan memberikan materi-materi tentang karya tulis ilmiah. Materi yang pertama diberikan adalah tentang pengertian dari karya tulis ilmiah dan ruang lingkup dari karya tulis. Materi yang kedua adalah tentang bagian-bagian yang harus ada pada karya tulis ilmiah dan urutan yang tepat dari bagian-bagian tersebut. Materi yang ketiga adalah kesalahan-kesalahan yang sering terjadi dalam penulisan karya tulis. Materi yang keempat adalah tentang macam-macam metode penelitian yang dipakai dalam penelitian. Materi yang terakhir adalah tentang pembuatan kuesioner yang baik.

Setelah mahasiswa diberikan materimateri tersebut, maka selanjutnya diberikan tugas untuk membuat karya tulis ilmiah dengan topik yang sesuai dengan program kelas mereka.

Karya tulis ilmiah yang telah mereka buat, kemudian dibahas satu persatu agar para mahasiswa mengetahui kesalahan mereka dan dapat menyempurnakan karya tulis mereka. Selain itu, para mahasiswa juga ditugaskan untuk membuat contoh kuesioner yang sesuai dengan topik karya tulis mereka.

\section{HASIL DAN PEMBAHASAN}

Pengertian karya tulis atau makalah menurut KBBI adalah tulisan resmi tentang suatu pokok yang dimaksudkan untuk dibacakan di muka umum dalam suatu persidangan dan yang sering disusun untuk diterbitkan. Pengertian lainnya adalah karya tulis pelajar atau mahasiswa sebagai laporan hasil pelaksanaan tugas sekolah atau perguruan tinggi. 
Karya tulis dibagi menjadi dua yaitu karya tulis ilmiah dan karya tulis popular. Karya tulis ilmiah adalah suatu laporan penulisan yang menjelaskan hasil dari suatu penelitian dengan menggunakan bahasa yang sesuai dengan bidang ilmu tertentu dan memenuhi etika penelitian. Contoh dari karya tulis ilmiah adalah skripsi, tesis, dan jurnal penelitian. Sementara itu, karya tulis populer adalah suatu laporan tulisan yang menjelaskan suatu fakta atau gagasan seseorang dan ditulis dengan menggunakan bahasabahasa populer sehingga mudah dipahami oleh masyarakat awam. Contoh dari karya tulis populer ini adalah artikel, resensi, dan sinopsis.

Untuk membuat suatu karya tulis ilmiah yang baik, biasanya karya tulis ini harus mengandung kaidah-kaidah tertentu yaitu: 1. Bersifat logis yang berarti harus dapat menjelaskan suatu permasalahan dengan tepat dan sesuai dengan teori-teori yang ada dalam logika ilmu tersebut 2. Adanya unsur objektivitas, di mana data-data yang dilaporkan dalam karya tulis adalah hasil yang sebenarnya, tidak mengarang 3 . Harus sistematis, yaitu penyajian data dilakukan berkesinambungan dan runut 4. Harus andal, yaitu hasil pelaporan telah teruji dan dapat dikaji ulang 5. Menggunakan bahasa yang baik dan benar sesuai dengan bidang keilmuannya (LIPI, 2012).

Dari berbagai pengertian yang ada pada dasarnya mempunyai arti yang sama namun dapat disimpulkan bahwa karya tulis merupakan hasil karya seseorang yang dituangkan dalam bentuk tulisan. Ciri-ciri karya tulis ilmiah:
1. Logis

Karya tulis dikatakan logis apabila data, argumen, penjelasan yang dikemukakan diterima oleh akal.

2. Sistematis

Karya tulis dikatakan sistematis apabila setiap permasalahan yang diuraikan disusun secara teratur, runtut, dan tidak tumpang tindih.

3. Obyektif

Karya tulis dikatakan obyektif apabila alasan, keterangan, penjelasan dan uraian-uraian yang dikemukakan sesuai apa adanya.

Ciri bahasa keilmuan karya ilmiah sebagai berikut:

1. Tidak ambigu, artinya tidak bermakna ganda.

2. Tidak emotif, artinya tidak melibatkan aspek perasaan penulis.

3. Menggunakan bahasa baku dalam ejaan, kata, kalimat dan paragraf.

4. Menggunakan istilah keilmuan.

5. Rasional, artinya penulis harus menonjolkan pikiran yang logis.

Ciri karya tulis non ilmiah diantaranya adalah:

1. Ditulis berdasarkan fakta pribadi

2. Fakta yang disimpulkan subyektif

3. Gaya bahasa konotatif dan popular

4. Tidak memuat hipotesis

5. Penyajian dibarengi dengan sejarah

6. Bersifat imajinatif

7. Situasi didramatisi

8. Bersifat persuasif

9. Tanpa dukungan bukti

Sedangkan yang ciri karya tulis populer diantaranya adalah:

1. Struktur sajian karya ilmiah sangat ketat, biasanya terdiri dari bagian awal, bagian inti dan bagian penutup. Bagian awal merupakan pengantar ke 
bagian inti, sedangkan inti merupakan sajian gagasan pokok yang ingin disampaikan.

2. Komponen karya ilmiah bervariasi sesuai dengan jenisnya, namun semua karya ilmiah mengandung pendahuluan, bagian inti, penutup, dan daftar pustaka. Artikel ilmiah yang dimuat dalam jurnal mempersyaratkan adanya abstrak.

3. Sikap penulis dalam karya ilmiah adalah objektif, yang disampaikan dengan menggunakan kata atau gaya bahasa impersonal

Bahasa yang digunakan dalam karya ilmiah adalah bahasa baku yang tercermin dari pilihan kata atau istilah, dan kalimatkalimat yang efektif dengan struktur yang baku.

Menurut (Dwiloka, 2005) karya tulis terbagi menjadi tiga jenis diantaranya adalah:

1. Karya tulis ilmiah merupakan hasil pemikiran ilmiah seorang ilmuan (yang berupa hasil pengembangan) yang ingin mengembangkan ilmu pengetahuan, teknologi, dan seni yang diperoleh melalui kepustakaan, kumpulan pengalaman, penelitian, dan pengetahuan orang lain sebelumnya.

2. Karya tulis non ilmiah merupakan karangan yang menyajikan fakta pribadi tentang pengetahuan dan pengalaman dalam kehidupan seharihari, bersifat subyektif, tidak didukung fakta umum, dan biasanya menggunakan gaya bahasa yang popular atau biasa digunakan (tidak terlalu formal).

3. Karya tulis ilmiah populer merupakan suatu karya yang ditulis dengan menggunakan bahasa yang populer sehingga mudah dipahami oleh masyarakat dan menarik untuk dibaca.

Untuk dapat mengerti pengertian karya tulis ilmiah populer, ada baiknya kita mengkajinya dari kata-kata pembentuknya yaitu tulisan, ilmiah, dan populer.

Contoh karya tulis dapat diambil dari jenis-jenis karya tulis, yang pertama untuk karya tulis ilmiah contohnya seperti :

1. Skripsi adalah karya ilmiah untuk memenuhi persyaratan mengakhiri studi S-1 dan mencapai gelar sarjana.

2. Tesis adalah tulisan ilmiah yang disusun untuk memenuhi persyaratan menempuh ujian S-2 dan mencapai gelar magister.

3. Disertasi adalah tulisan ilmiah yang disusun untuk mencapai derajat akademis doktor atau S-3.

4. Makalah adalah karya ilmiah yang pembahasannya berdasarkan data di lapangan yang bersifat empirisobjektif. Biasanya disusun guna memenuhi tugas-tugas mata kuliah.

5. Proposal penelitian merupakan karya ilmiah yang dibuat sebelum menyusun skripsi, tesis, atau disertasi.

Contoh karya tulis non ilmiah, diantaranya adalah:

1. Dongeng

Merupakan suatu kisah yang diangkat dari pemikiran fiktif dan kisah nyata, menjadi suatu alur perjalanan hidup dengan pesan moral yang mengandung makna hidup dan cara berinteraksi dengan makhluk lainnya. 
2. Cerpen

Adalah suatu bentuk prosa naratif fiktif. Cerita pendek cenderung padat dan langsung pada tujuannya dibandingkan karya-karya fiksi yang lebih panjang, seperti novella (dalam pengertian modern) dan novel.

3. Novel

Adalah sebuah karya fiksi prosa yang ditulis secara naratif; biasanya dalam bentuk cerita.

4. Drama

Adalah satu bentuk karya sastra yang memiliki bagian untuk diperankan oleh aktor.

5. Roman

adalah sejenis karya sastra dalam bentuk prosa atau gancaran yang isinya melukiskan perbuatan pelakunya menurut watak dan isi jiwa masing-masing.

Contoh karya tulis ilmiah populer, contohnya seperti :

1. Artikel adalah karangan faktual secara lengkap dengan panjang tertentu yang dibuat untuk dipublikasikan (melalui koran, majalah, buletin, dsb.) dan bertujuan menyampaikan gagasan dan fakta yang dapat meyakinkan, mendidik, dan menghibur.

2. Resensi adalah suatu tulisan atau ulasan mengenai nilai sebuah hasil karya, baik itu buku, novel, majalah, komik, film, kaset, CD, VCD, maupun DVD.

3. Resume atau ringkasan

4. Sinopsis adalah ikhtisar karangan yang biasanya diterbitkan bersamasama dengan karangan asli yang menjadi dasar sinopsis itu; ringkasan; abstraksi.
Karya tulis ilmiah memiliki banyak manfaat bagi penulis maupun yang membaca. Manfaat untuk penulis sendiri adalah dapat menjadi sarana pelatihan untuk menyampaikan hasil laporan penelitian dengan baik. Kemudian dapat menjadi sarana pembuktian bahwa penulis bukan hanya menikmati hasil penelitian, tetapi juga mampu menghasilkan penelitian yang bermanfaat. Untuk pembaca, manfaat yang didapatkan adalah mengetahui penelitian- penelitian terbaru yang bermanfaat, memperluas ilmu pengetahuan, dan memunculkan ide-ide penelitian yang baru.

Untuk menuliskan suatu karya tulis ilmiah tidaklah mudah karena karya tulis tersebut akan dibaca oleh banyak orang dan berbagai kalangan masyarakat sehingga penulisannya harus menggunakan bahasa yang baku, jelas, tidak ambigu, serta menggunakan katakata ilmiah yang tepat sesuai dengan bidangnya. Untuk dapat menulis dengan bahasa yang baik dan tepat maka diperlukan pelatihan-pelatihan cara penulisan. Tidak hanya pelatihan menulis, para penulis juga dituntut untuk membaca banyak referensi-referensi ilmiah lainnya sehingga karya tulisnya menjadi lebih berbobot.

Dalam karya tulis ilmiah, terdapat etika penulisan yang harus dipatuhi, salah satunya adalah penulisan rujukan. Semua rujukan yang diambil dari jurnal-jurnal penelitian maupun buku-buku, harus dimasukkan ke dalam daftar pustaka. Jika tidak dimasukkan, maka penulis tersebut melakukan plagiarisme. Plagiarisme sendiri memiliki pengertian yaitu mengambil atau menulis gagasan atau ide 
orang lain tanpa memberikan penghargaan kepada orang tersebut (LIPI, 2012).

Plagiarisme sangat dilarang dalam penulisan karya tulis ilmiah dan apabila diketahui maka akan mendapatkan sanksi yang berat. Di Indonesia sendiri, kasus plagiarisme banyak terjadi di berbagai bidang. Para akademisi dan peneliti pun pernah tersandung kasus ini dan mendapatkan sanksi yang berat seperti dicabutnya gelar pendidikan yang telah didapatkannya dan dicap sebagai plagiat. Tidak hanya di Indonesia, kasus plagiarisme juga banyak terjadi di luar negeri. Oleh karena itu, para penulis harus berhati-hati dan teliti dalam menuliskan karya tulisnya agar tidak dicap sebagai plagiat.

Kerangka pemecahan masalah secara operasional sebagai berikut:

1. Penyelenggaraan pelatihan intensif tentang:

a. Peluang dan manfaat penulisan karya ilmiah berupa laporan penelitian

b. Penulisan karya ilmiah berupa laporan penelitian mencangkup:

c. Teknik mengidentifikasi, memilih dan merumuskan topik/judul karya tulis ilmiah.

d. Teknik menyusun kerangka tulisan karya ilmiah.

e. Teknik mengumpulkan bahanbahan tulisan, mengorganisasikan, dan mengonsep karya tulis ilmiah, dan

f. Teknik menulis dan menyunting karya ilmiah
2. Aplikasi tentang berbagai hal yang telah dipelajari dari pelatihan dengan pendampingan dan supervisi dari tim pengabdian masyarakat.

Sistematika karya tulis ilmiah biasanya berbeda-beda, tergantung pada ketentuan yang diberikan. Namun, pada dasarnya sistematika karya tulis ilmiah tersebut memuat bagian- bagian yang sama, seperti terdapat abstrak, pendahuluan, tinjauan pustaka, metode penelitian, hasil dan pembahasan, kesimpulan, serta daftar pustaka. Pada bagian abstrak mengandung ringkasan dari karya tulis tersebut, mulai dari pendahuluan hingga hasil dan pembahasan. Kemudian, pada bagian pendahuluan biasanya terdiri dari latar belakang, rumusan masalah, ruang lingkup, dan tujuan dari penelitian yang akan dilakukan. Pada bagian tinjauan pustaka, biasanya akan dijelaskan tentang teori-teori atau penelitianpenelitian yang telah dilakukan untuk mendukung penelitian tersebut. Dalam metode penelitian, penulis akan menulis metode apa saja yang digunakan dalam penelitian. Bagian hasil dan pembahasan akan menerangkan tentang hasil penelitian dan membahas makna dari penemuan penelitian tersebut. Bagian yang terakhir adalah daftar pustaka di mana bagian ini berisi tentang semua rujukan yang kita gunakan dalam penulisan karya tulis. Untuk penulisan daftar pustaka biasanya juga diatur dalam pedoman penulisan, sehingga penulis harus mengikuti ketentuan yang ada.

Sebelum diberikan pelatihan penulisan tersebut, para remaja di kelurahan Tembilahan Barat 
mengeluhkan bahwa mereka sulit untuk membuat karya tulis ilmiah yang baik. Kesulitan yang para siswa rasakan tampak jelas dari karya tulis yang mereka buat, di mana karya tulis tersebut tidak sistematis, tidak logis, bahasanya sulit dipahami dan ambigu, serta kalimat- kalimatnya juga selalu di ulang. Kesulitan- kesulitan tersebut terjadi karena para guru yang ada kurang mampu memberikan arahan yang tepat untuk menulis karya tulis. Kekurangan para guru ini sangat mungkin terjadi apabila guru-guru tersebut jarang mengasah kemampuan menulis mereka. Selain itu, kemungkinan besar lainnya adalah para guru malas untuk mengoreksi karya tulis mereka sehingga para mahasiswa percaya bahwa karya tulis tersebut baik dan benar.

Masalah lainnya yang sangat fatal terjadi adalah metode penelitian yang mereka gunakan tidak sesuai dengan judul penelitian mereka. Metode penelitian yang mereka gunakan tidak valid sehingga hasil penelitiannya tidak dapat dipertanggungjawabkan. Contohnya adalah salah satu karya tulis ilmiah mereka yang berjudul pemanfaatan daun saga sebagai obat batuk, di mana metode penelitian yang mereka lakukan hanya dengan meminta beberapa orang yang sedang batuk untuk meminum ekstrak daun saga dan melihat perkembangan kondisi kesehatan orang tersebut setelah meminum ekstrak daun tersebut.

Hasil penelitian yang mereka laporkan hanya berupa pernyataan bahwa orang tersebut telah berkurang batuknya setelah tiga hari meminum ekstrak daun tersebut. Hasil penelitian tersebut tidak dapat diukur, karena hanya dengan melihat apakah orang tersebut telah berkurang batuknya, padahal sudut pandang setiap orang dalam kesembuhan berbeda-beda. Kemudian pada bagian tinjauan pustaka, mereka tidak mencantumkan teori-teori atau penelitian sebelumnya yang dapat mendukung hipotesis mereka, sehingga dapat menyebabkan para pembaca kemungkinan besar tidak akan percaya dengan penelitian tersebut.

Pada saat pelatihan, diberikan lima materi utama. Tujuan pada materi yang pertama adalah untuk mengenalkan kepada remaja apa arti karya tulis ilmiah yang sebenarnya dan tujuan pembuatan karya tulis ilmiah. Materi kedua yang diberikan bertujuan untuk memberitahukan kepada remaja bagianbagian apa yang penting untuk dijelaskan dan bagian mana yang tidak penting untuk dijelaskan. Materi ketiga ini bertujuan untuk menginformasikan kepada remaja etika seperti apa yang harus dipatuhi oleh para penulis ketika membuat karya tulis ilmiah dan sanksi apa yang akan didapatkan jika melanggar etika penulisan tersebut. Materi keempat diberikan bertujuan agar para remaja mengerti metode penelitian yang valid dan dapat dipertanggungjawabkan hasilnya. Kemudian, materi terakhir yang diberikan bertujuan agar para remaja yang ingin membuat kuesioner dapat membuat kuesioner yang benar dan tepat sasarannya.

Setelah selesai dilakukan pelatihan tersebut, kemudian para mahasiswa ditugaskan untuk membuat karya tulis secara berkelompok sesuai dengan bidangnya masing-masing. Setelah 
mendapatkan pelatihan tersebut, dapat terlihat bahwa mereka sedikit demi sedikit mampu membuat karya tulis ilmiah yang sesuai dengan kaidah yang ada. Hal ini dapat terlihat dari sistematika penulisan karya tulis yang menjadi runut dan logis. Kemudian, mereka juga mampu menulis dengan bahasa Indonesia yang baik dan benar, serta kalimat yang digunakan tidak di ulang-ulang. Mereka juga telah mampu mencantumkan teori-teori atau fakta-fakta yang dapat mendukung penelitian mereka. Setelah itu, mereka mulai dapat memikirkan metode yang tepat untuk digunakan dalam penelitian mereka. Hal yang paling penting adalah mereka mulai memiliki kepercayaan diri lagi dalam menulis karya ilmiah.

\section{SIMPULAN}

Kegiatan pelatihan penulisan karya tulis ilmiah ini dapat mengubah cara pandang mahasiswa dalam menulis karya tulis ilmiah, sehingga mereka sedikit demi sedikit mampu membuat karya tulis ilmiah yang baik dan benar. Selain itu, tumbuhnya rasa kepercayaan diri pada setiap mahasiswa untuk menyelesaikan penulisan skripsi yang baik dan benar.

\section{DAFTAR PUSTAKA}

Abas, S. (2006). Pembelajaran Bahasa Indonesia yang Aktif di Sekolah Dasar. Jakarta: Depdiknas.

Dwiloka, B. D. (2005). Teknik Menulis Karya Ilmiah. Jakarta: Rineka Press.

Khadarsiah, A. L. (2012). Upaya Meningkatkan Keterampilan Menulis Karangan Narasi dengan Media Gambar Seri pada Mata Pelajaran Bahasa Indoesia Kelas IV MI AL-Ihsan Medari Sleman
Yogyakarta Tahun Ajaran

2011/2012. Digilib UIN, Yogyakarta

LIPI. (2012). Pedoman Karya Tulis Ilmiah. Jakarta: LIPI.

Nurjamal, D., Sumirat, W., Darwis, R. (2011). Terampil Berbahasa Menyusun Karya Tulis Akademik, Memancu Acara, dan Menulis Surat. Bandung: Alfabeta.

Suherli, K. (2010). Merancang karya tulis ilmiah. Bandung: Rosdakarya.

Syafie'ie, I Imam. (1988). Retorika dalam Menulis. Jakarta.: P2LPTK Depdikbud.

Tarigan, Henry, G. (1986). Menulis Sebagai Suatu Keterampilan Berbahasa. Bandung: Penerbit Angkasa.

Widiastuti, W. (2013). Meningkatkan Kemampuan Membaca dan Menulis Narasi dengan Penerapan Model Pembelajaran Koperatif Tipe ThinkPair- Share. Bandung: Repositori UPI.

\footnotetext{
ABDIMASY: Jurnal Pengabdian dan Pemberdayaan Masyarakat 